Bangladesh J. Plant Taxon. 26(1): 57-68, 2019 (June)

(C) 2019 Bangladesh Association of Plant Taxonomists

\title{
MORPHOANATOMICAL PROFILE OF FIVE SPECIES OF PIPER L. FROM BANGLADESH AND ITS TAXONOMIC SIGNIFICANCE
}

\author{
Kishwar Jahan Shethi ${ }^{1}$, Parveen Rashid, Momtaz Begum and M. Oliur Rahman ${ }^{2}$ \\ Department of Botany, University of Dhaka, Dhaka-1000, Bangladesh
}

Keywords: Piper L.; Taxonomy; Anatomy; Stomata; Trichome; Idioblast.

\begin{abstract}
The present study explores detailed morphoanatomical features of five species of Piper L., viz. $P$. betle L., $P$. longum L., $P$. nigrum L., $P$. retrofractum Vahl and $P$. sylvaticum Roxb. Each species is supplemented by detailed updated nomenclature, vernacular names, diagnostic characters, phenology, ecology and representative specimens. Maximum number of cortical and medullary vascular bundles have been observed in $P$. nigrum and $P$. retrofractum, respectively. In contrast, minimum number of cortical and medullary vascular bundles have been found in P. sylvaticum. Glandular trichomes are found on the midrib of $P$. betle, P. longum, and $P$. sylvaticum, whereas trichomes are lacking in $P$. nigrum and $P$. retrofractum. The highest number of collateral vascular bundles have been found in $P$. retrofractum followed by $P$. nigrum, while $P$. betle and $P$. longum contain single collateral vascular bundle. $P$. betle can easily be distinguished from other species by its oval stem, non-glandular multicellular trichome with pointed tip, and presence of idioblasts and oil droplets. P. longum is distinct from remaining species by its diacytic stomata. Keys to the species based on morphological and anatomical characters are provided for easy identification of the studied species.
\end{abstract}

\section{Introduction}

The genus Piper L. (Piperaceae) consists of over 1,000 species and distributed pantropically, and the greatest diversity of Piper species occurs in the American tropics followed by Southern Asia (Jaramillo and Manos, 2001). The centers of Piper species diversification are southeast Asia, southern Mexico, the Andes, the Choco, Amazonia and the Atlantic forest of Brazil (Jaramillo and Callejas, 2004). This is the best known genus of the family Piperaceae probably for its scientific and commercial importance (Murty, 1973). The species of Piper are suitable for studying natural history, molecular biology, natural products biochemistry, community ecology and evolutionary biology (Greig, 2004). Hooker (1886) listed 45 species of Piper from Indian subcontinent of which 6 were documented from the present territory of Bangladesh. Later, Prain (1903) recognized 8 species of this genus from the then Bengal where he listed 6 species from the area of present Bangladesh. Recently, Habib (2009) listed 10 Piper species from Bangladesh, viz. Piper attenuatum Buch.-Ham. ex Wall., P. betle L., P. hamiltonii C. DC., P. longum L., P. nigrum L., $P$. peepuloides Roxb., P. retrofractum Vahl, P. rhytidocarpum Hook. f., P. sylvaticum Roxb., and $P$. sylvestre Lamk.; among them some are regarded as very rare and vulnerable.

Many Piper species are rather uniform morphologically, with simple, alternate leaves and jointed stems with enlarged nodes (Greig, 2004). Moreover, some of these species are monoecious or dioecious, and it is sometimes difficult to identify and classify them by using only morphological characteristics. Other alternative methods, therefore, are needed for systematics of Piper (Chaveerach et al., 2002). In this context, anatomical studies have significant role to provide

\footnotetext{
${ }^{1}$ Corresponding author, Email: kishwar.botany@ du.ac.bd

2 Email: oliur.bot@du.ac.bd ; prof.oliurrahman@gmail.com
} 
additional data for solving taxonomic problems. Despite the varied importance of this genus, little anatomical studies have been done on different species of Piper across the world (Ravindran and Rameshree, 1998; Lakshmi and Naidu, 2010; Raman et al., 2012; Machado et al., 2015; Trueba et al., 2015; Bertocco et al., 2017; Silva et al., 2017). Most of the anatomical studies are concentrated on economically important and widely known species, e.g. $P$. nigrum, $P$. betle and $P$. longum. However, no investigation on the micromorphology of $P$. retrofractum and $P$. sylvaticum has been documented so far.

Moreover, no anatomical study on the available and economically important species of Piper from Bangladesh has been conducted so far. Among the 10 reported species of Piper, five species have been selected primarily for anatomical investigation in the present study because of their availability. Two of these are economically important e.g. P. nigrum, which is the source of black pepper, the world's most widely used spice and $P$. betle, leaves of which are chewed along with lime (calcium) after meals as a digestive aid. P. longum and P. retrofractum are used locally as condiments or medicinal and found to possess significant antitubercular and antibacterial activity, respectively (Ghani, 2003). However, P. sylvaticum is very little known economically, though Sinha (1996) demonstrated that fruits of this species are used as carminative and appetizer in Manipur, India. Considering the morphological similarities among different species of Piper, and the fact that there has been no comparative anatomical study of the aforesaid five Piper species, the present study aims to explore morphology of these Piper species along with their detailed anatomical features of leaf and stem for delimitation of the species and interspecific relationships.

\section{Materials and Methods}

\section{Plant materials}

Plant specimens of five Piper L. species, viz. P. betle, P. longum, P. nigrum, P. retrofractum and $P$. sylvaticum have been collected from different districts of Bangladesh, critically studied and identified. Identifications were confirmed by consulting standard relevant literature (Hooker, 1886; Prain, 1903; Hubert, 1987; Yongqian et al., 1999), experts and matching with the properly identified herbarium specimens deposited at Dhaka University Salar Khan Herbarium (DUSH) and Bangladesh National Herbarium (DACB). Specimens belonging to these five species housed at DUSH and DACB were also studied. Updated nomenclature of the species are confirmed with consulting Encyclopedia of Flora and Fauna of Bangladesh (Habib, 2009), and the nomenclatural databases of The Plant List (2013) and TROPICOS (2017).

\section{Anatomical investigation}

Fresh specimens were collected from the Botanical garden and Medicinal Plants garden, Department of Botany, University of Dhaka for the study of the internal structures of the studied species of Piper. Vegetative organs namely, stem and leaf were chosen as they might provide discrete anatomical features of taxonomic importance. Free hand sectioning of stem and leaf was made with the help of a razor blade. The sections were stained with safranin and mounted in $20 \%$ glycerin (Shethi et al., 2017). After that, selected sections were prepared as permanent slides. The permanent slides were studied under a compound light microscope (Carl Zeiss Lab A1 microscope) fitted with digital camera (Axiocam ERc 5s). Micrographs were taken from various regions of the sections using different magnifications through Axio Vision Release 4.8.2 software. 


\section{Results and Discussion}

\section{Morphological investigation of Piper $\mathbf{L}$.}

The members of the genus Piper L. are climbing herbs or shrubs with swollen nodes, often glandular and aromatic. They are characterized by their palmate, alternate leaves, often oblique; minute unisexulal flowers in spike, peltate bracts and absence of perianth. Male flowers with 1-4 stamens, short filament and 2-celled anthers, while female flowers with unilocular ovary and 2-5 stigmas. Fruits are ovoid or globose drupe.

Key to the species of Piper employed in this study based on morphological characters:

1. Perennial herbs, prostrate or ascending. Twining or woody climbers or shrubs.

2. Flowers yellow; leaf base deeply cordate with lobed.

- $\quad$ Flowers greenish-white or pinkish-white; leaf base not lobed.

3. Female spikes densely pubescent; stamens never more than 2. Female spikes glabrous; stamens more than 2.
Piper longum P. sylvaticum

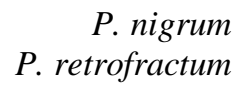

4. Leaf base rounded, apex acute, densely glandular-dotted; spikes pendent.

- Leaf base oblique, apex acuminate, glabrous; spikes erect.

Piper betle L., Sp. Pl.: 28 (1753). Hook. f., Fl. Brit. India 5: 85 (1886); Prain, Beng. Pl. 2: 668 (1903); Heinig, List Pl. Chitt. Coll. \& HT: 56 (1925); Sinclair, Bull. Bot. Soc. Beng. 9(2): 105 (1956); Habib in Ahmed et al. (Eds), Encycl. Fl. Fauna Bangladesh 9: 372 (2009). Chavica betle (L.) Miq., Syst. Piperac.: 228 (1843). P. pinguispicum C. DC. \& Koord., Excurs. Fl. Java 2: 24 (1912).

(Fig. 1A).

Vernacular names: Pan (B); Betel-leaf (E).

Perennial, stout twining climbers, branches with swollen nodes; short adventitious roots present at the nodes. Leaves simple, alternate, petiolate, lamina cordate or ovate-oblong, base cordate or oblique, acuminate, entire. Bracts orbicular, peltate. Spike pendulous, cylindrical. Rachis of female spikes fleshy, densely pubescent. Drupe small, ovoid or globose, fleshy. Seeds suborbicular.

Flowering and fruiting: December - May.

Ecology: Dry shady place in well-drained, friable loamy and clayey soil.

Representative specimens: Gazipur: Kaliakoir, Hijoltoli, 13.09.2013, R. Tabassum 3051 (DUSH). Patuakhali: Golachipa, Nolubabhi, 31.03.1999, M. Sultana 231 (DUSH).

Piper longum L., Sp. Pl.: 29 (1753). Hook. f., Fl. Brit. India 5: 83 (1886); Prain, Beng. Pl. 2: 668 (1903); Habib in Ahmed et al. (Eds), Encycl. Fl. Fauna Bangladesh 9: 373 (2009). P. latifolium Hunter in Asiat. Res.: 9 (1809). Chavica roxburghii Miq., Syst. Piperac.: 239 (1843). $\quad$ (Fig. 1B).

Vernacular names: Pipul, Pipla-mul, Morich (B); Indian Long Pepper, Long Pepper (E).

Perennial, creeping or rambling, dioecious herbs, rooting at the nodes. Leaves simple, alternate, petiolate, lamina lanceolate to ovate-lanceolate, base cordate, apex acute or acuminate. Male spikes 5-10 cm long. Female spikes 2-3 cm long. Flowers small, white or pinkish-white. Stamens 2; filaments short; anther cells inclined. Ovary sunken in thick rachis; stigmas 3-4, large. Drupe large, pungent. Seeds cylindrical.

Flowering and fruiting: June - September. 
Ecology: Shaded areas of forest bed.

Representative specimens: Gazipur: Sripur, Borkol, 21.06.2010, R. Tabassum 1139 (DUSH). Mymensingh: sin loc., 25.01.1999, M. M. Rahman 3505 (DUSH). Netrokona: Bijoypur, Durgapur, 14.06.2015, M. O. Rahman (DUSH). Patuakhali: Sadar upazila, Joinkathi, 25.09.1999, M. Sultana 397 (DUSH).

Piper nigrum L., Sp. Pl.: 28 (1753). Hook. f., Fl. Brit. India 5: 90 (1886); Prain, Beng. Pl. 2: 669 (1903); Heinig, List Pl. Chitt. Coll. \& HT: 56 (1925); Habib in Ahmed et al. (Eds), Encycl. Fl. Fauna Bangladesh 9: 374 (2009). P. aromaticum Lamk., Tabl. Encycl. 1: 79 (1791).

(Fig. 1C).

Vernacular names: Gol Morich, Kali Morich (B); Black Pepper, Round Pepper (E).

Perennial woody climbers, branches with swollen nodes, rooting at the nodes. Leaves simple, alternate, petiolate, petioles up to $5 \mathrm{~cm}$ long, lamina ovate-lanceolate, oblique to rounded at the base, acuminate, entire, glabrous, densely glandular dotted beneath, coriaceous. Flowers greenish in interrupted spikes. Spikes appearing opposite the leaves on plagiotropic branches, 3-15 cm long, 50-150 flowered. Male spikes slender, stamens $2-4$. Female spikes cylindric, ovary superior; stigmas 3-5. Drupe globose, red when ripe. Seeds globose.

Flowering and fruiting: August - December.

Ecology: Shaded places.

Representative specimens: Chittagong Hill Tracts: Ruma, 25.01.1965, M.S. Khan 1129 (DUSH). Gazipur: Sripur, Boherar chala, 21.10.2013, R. Tabasum 3379 (DUSH).

Piper retrofractum Vahl, Enum. 1: 314 (1804). Habib in Ahmed et al. (Eds), Encycl. Fl. Fauna Bangladesh 9: 376 (2009). P. chaba Hunter, Asiat. Res. 9: 391 (1809); Hook. f., Fl. Brit. India 5: 83 (1886); Prain, Beng. Pl. 2: 668 (1903); Heinig, List Pl. Chitta. Coll. \& HT: 55 (1925). P. officinarum (Miq.) C. DC., Prodr. 16(1): 356 (1869).

(Fig. 1D).

Vernacular names: Choi, Chab, Choitro (B); Javanese Long Pepper (E).

Perennial climbing shrub with short adventitious roots at the swollen nodes. Leaves simple, petiolate, alternate, lamina ovate-oblong, base cordate, oblique, apex acuminate, entire, glabrous. Spikes erect or patent, peduncles $1-3 \mathrm{~cm}$ long; bracts broadly ovate. Male spikes $2-6 \mathrm{~cm} \mathrm{long}$, stamens 2-3; filament short, persistent; anthers broadly ellipsoid. Female spike 2-4 cm long, ovary superior, ovule 1; style short; stigmas $2-3$, ovate, acute, recurved. Drupe broadly round, hard, pungent. Seeds globose.

Flowering and fruiting: Almost throughout the year.

Ecology: Moist shady places.

Representative specimen: Jessore: 26.12.2017, Momtaz Begum 103 (DUSH).

Piper sylvaticum Roxb., Fl. Ind. 1: 158 (1820). Hook. f., Fl. Brit. India 5: 84 (1886); Prain, Beng. Pl. 2: 668 (1903); Habib in Ahmed et al. (Eds), Encycl. Fl. Fauna Bangladesh 9: 377 (2009). Chavica sylvatica Miq., Syst. Piperac. : 248 (1843).

(Fig. 1E).

Vernacular names: Pahari Pipul, Bon Pan (B); Bulpan (Ch); Borongpatui (Tr).

Small climbing shrub with short, erect branches. Leaves simple, alternate, petiolate, petioles $1.0-2.5 \mathrm{~cm}$ long, lamina 7-13 $\times 3-7 \mathrm{~cm}$, broadly ovate-lanceolate, base cuneate or rounded, apex acuminate, 5-veined at the base. Flowers in axillary spikes, yellow. Male spikes subsessile, slender, erect, bracts peltate; stamens 4; filament short; anthers reniform, 2-celled. Female spikes 
cylindric, peduncles short; ovary superior, globose, 1-celled, ovule 1; style short; stigmas 2-3. Drupe globose, 3-4 mm long, densely arranged, 1-seeded. Seeds globose.

Flowering and fruiting: May - September.

Ecology: Shaded areas of forest bed.

Representative specimens: Gopalganj: Tungipara, 29.09.2018, Momtaz Begum 262 (DUSH); Chilkabari, Momtaz Begum 321 (DUSH).

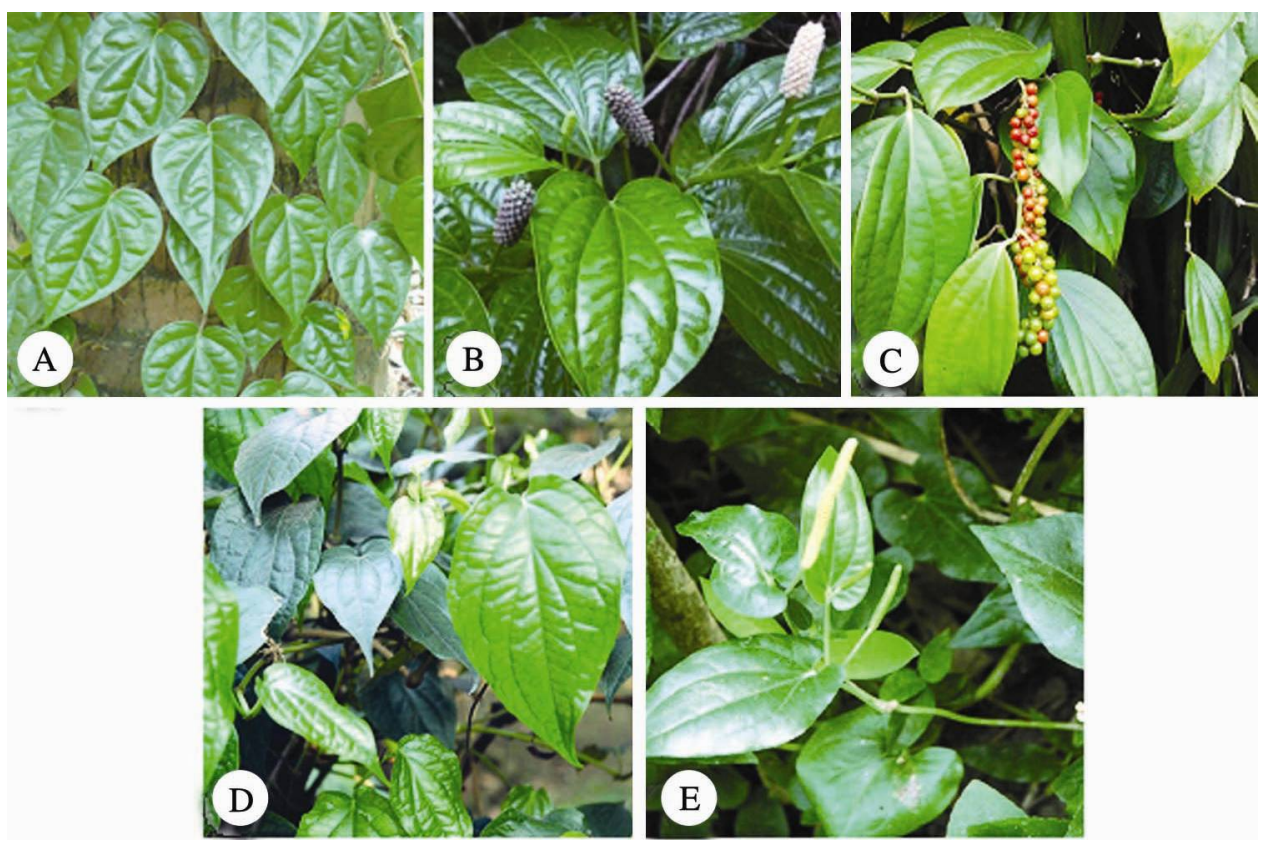

Fig. 1. Habit of five Piper L. species investigated: A. Piper betle; B. P. longum; C. Piper nigrum; D. P. retrofractum; E. P. sylvaticum.

\section{Anatomical investigation of Piper}

\section{Stem anatomy}

Transverse section of stem reveals variation among the five species of Piper investigated. The contour of stem is round in $P$. longum, $P$. nigrum, $P$. retrofractum and $P$. sylvaticum (Fig. 2A-D), while oval in P. betle (Fig. 2E). Margin of the studied species has ridges and furrows except in $P$. retrofractrum. Except $P$. retrofractrum, all the studied species of Piper contain nonglandular, unicellular and conical shaped trichomes (Fig. 2G) other than P. betle. In P. betle, nonglandular trichomes are multicellular and typically 4-celled with pointed tip, less frequent and present in regular intervals of 2-3 groups (Fig. 2H). Raman et al. (2012), and Lakshmi and Naidu (2010) reported similar trichome in P. betle which is congruent with the present study. Small, numerous, non-glandular unicellular trichomes are distributed on the stem of $P$. longum and $P$. nigrum, while very few are observed in P. sylvaticum. Cuticle of the epidermis of stem of the investigated species of Piper is thick (Fig. 2F). In general, epidermal layer is followed by cortex, and the cortex possesses three types of cells - collenchyma, chlorenchyma and parenchyma. Outer cortex is collenchymatous, where layers of cells varied among the species depending on maturity. 

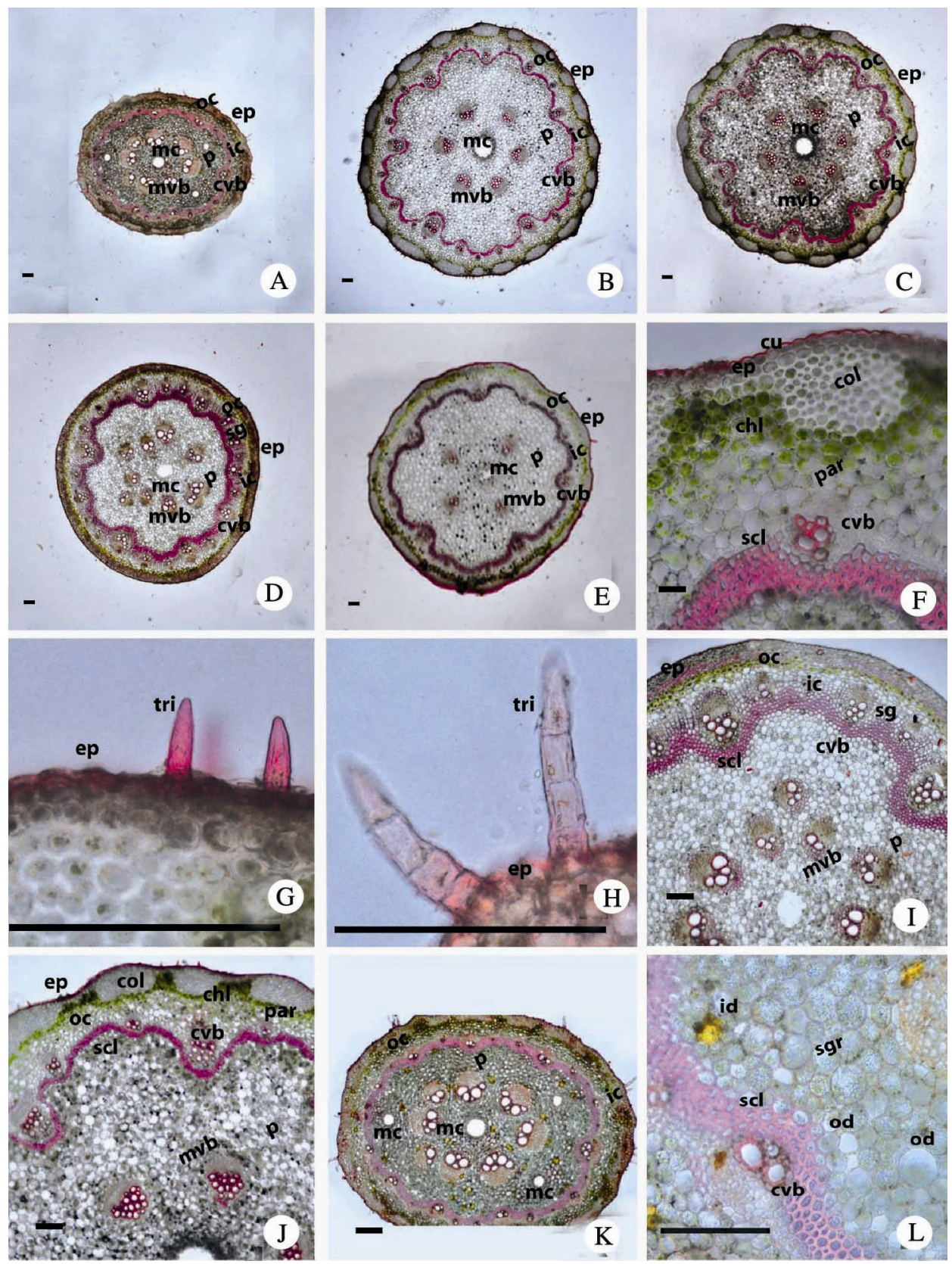

Fig. 2. Transverse section of stem showing contour and detailed anatomical characters of five species of Piper: A. P. betle (4X); B. P. longum (4X); C. P. nigrum (4X); D. P. retrofractum (4X); E. P. sylvaticum (4X); F. $P$. nigrum (40X); G. Trichome of P. nigrum (100X); H. Trichome of P. betle (100X); I. P. retrofractum (10X); J. P. nigrum (100X); K-L. P. betle (100X). ep: epidermis, oc: outer cortex, ic: inner cortex, cvb: cortical vascular bundle, mvb: medullary vascular bundle, p: pith, mc: mucilage canal, cu: cuticle, col: collenchyma, chl: chlorenchyma, par: parenchyma, scl: sclerenchyma, tri: trichome, sgr: starch grain, od: oil duct. Bar $=100 \mu \mathrm{m}$. 
Outer collenchymatous cortex is followed by sclerenchyma layer of cells forming continuous ring beneath the epidermis only in $P$. retrofractum (Fig. 2I). However, in other four species outer collenchymatous layer is interrupted and separated by the extension of inner cortex, which are usually the chlorenchymatous layer of cells (Fig. 2J). Except the extension, cells of inner cortex of all the species are parenchymatous in nature.

A comparative account of stem anatomical characters among the five species of Piper has been depicted in Table 1. The highest number of cortical vascular bundles are found in P. nigrum followed by $P$. betle and $P$. longum, while the lowest number is noticed in P. sylvaticum. The number of medullary vascular bundles remains the same in $P$. longum and $P$. nigrum showing a close affinity among these species. Piper betle can easily be distinguished from other species by its oval shaped stem, non-glandular, multicellular trichomes with pointed tip, and presence of idioblasts and oil droplets (Table 1).

Table 1. Comparative anatomy of stem of five species of Piper $\mathbf{L}$.

\begin{tabular}{|c|c|c|c|c|c|}
\hline Features & P. betle & P. longum & P. nigrum & P. retrofractum & P. sylvaticum \\
\hline $\begin{array}{l}\text { Shape and } \\
\text { Outline }\end{array}$ & $\begin{array}{l}\text { Oval, outline } \\
\text { with ridges and } \\
\text { furrows }\end{array}$ & $\begin{array}{l}\text { Round, outline } \\
\text { with prominent } \\
\text { ridges and } \\
\text { furrows }\end{array}$ & $\begin{array}{l}\text { Round, } \\
\text { outline with } \\
\text { prominent } \\
\text { ridges and } \\
\text { furrows }\end{array}$ & $\begin{array}{l}\text { Round, no } \\
\text { ridges and } \\
\text { furrows in } \\
\text { outline }\end{array}$ & $\begin{array}{l}\text { Round, with } \\
\text { negligible } \\
\text { ridges and } \\
\text { furrows in } \\
\text { outline }\end{array}$ \\
\hline Trichome & $\begin{array}{l}\text { Non-glandular, } \\
\text { multicellular } \\
\text { (4-celled) with } \\
\text { pointed tip, less } \\
\text { frequent }\end{array}$ & $\begin{array}{l}\text { Non-glandular, } \\
\text { unicellular, } \\
\text { frequent }\end{array}$ & $\begin{array}{l}\text { Non- } \\
\text { glandular, } \\
\text { small, } \\
\text { unicellular, } \\
\text { frequent }\end{array}$ & Absent & $\begin{array}{l}\text { Non-glandular, } \\
\text { unicellular, } \\
\text { small, scarcely } \\
\text { present }\end{array}$ \\
\hline $\begin{array}{l}\text { No. of cortical } \\
\text { vascular bundle }\end{array}$ & 25 & 25 & 26 & 22 & 15 \\
\hline $\begin{array}{l}\text { No. of medullary } \\
\text { vascular bundle }\end{array}$ & 8 & 6 & 6 & 10 & 4 \\
\hline Mucilage canal & $\begin{array}{l}1 \text { central, } 3 \\
\text { between } \\
\text { medullary and } \\
\text { cortical vascular } \\
\text { bundle }\end{array}$ & 1 , central & 1 , central & 1 , central & 1 , central \\
\hline $\begin{array}{l}\text { Idioblasts and oil } \\
\text { droplets }\end{array}$ & Numerous & Absent & Absent & Absent & Absent \\
\hline
\end{tabular}

Anomalous secondary structure in the stem anatomy is a diagnostic feature of the family Piperaceae. Vascular bundle type in the studied species of Piper stem was conjoint, collateral, open and arranged in two rings, i.e. the outer cortical/peripheral ring and the inner medullary ring (Fig. 2A-E). The bundles of the cortical ring are always greater in number than the medullary ring and are not uniform in size (Murty, 1973). Number of vascular bundles in both rings are different among the studied species (Table 1). Maximum number of cortical and medullary vascular bundles are observed in $P$. betle followed by $P$. nigrum and $P$. retrofractum. On the other hand, minimum number of cortical and medullary vascular bundles are found in $P$. sylvaticum. The number of vascular bundles in both rings in $P$. longum and $P$. nigrum is incongruent with earlier studies (Murty, 1973; Ravindran and Rameshree, 1998). Similar number of cortical vascular bundles (25) are observed in P. betle which is consistent with Murty (1973). The medullary vascular bundles are larger than the cortical/peripheral vascular bundles. 
The vascular bundles in the peripheral ring consist of small and large bundles arranged alternately. Below the peripheral vascular bundle area, a continuous wavy band of several layered (number of layers might vary according to the species and age) sclerenchymatous conjunctive tissue is observed, and the lower part of xylem region merges with these layers. Secondary thickening is restricted to the peripheral vascular bundles only (Fig. 2I). Xylem of both the vascular bundles is highly lignified but the newly produced metaxylem elements are unlignified. The centre of the stem is occupied by a large, lysigenous type of mucilage duct/canal in the studied species. In addition, $P$. betle has three more mucilage duct between the ring of peripheral and medullary vascular bundles (Fig. 2K). However, both central and cortical mucilage canal are reported in P. nigrum (Ravindran and Rameshree, 1998). The pith is larger, and occupies much of the volume of stem; composed of parenchyma cells that contain much starch grains (Fig. 2L).

Starch grains are present in other tissue of the stem of the Piper species, and P. betle contains more starch grain than other species. In the present investigation deposition of secretory idioblasts (orange in colour and generally known as oleoresins) and oil droplets are observed frequently in different tissues of $P$. betle stem (Fig. 2K-L). Though oil droplets are present occasionally in different tissues of the stem of other studied species, no oleoresins are present in other species. However, occurrence of such compounds are reported to be common in other species of Piper by many workers (Silva et al., 2014; Machado et al., 2015; Santos et al., 2015; Bertocco et al., 2017).

\section{Leaf anatomy}

Transverse section of the dorsiventral leaves of the five species of Piper provides diverse anatomical features in both leaf blade and midrib region. Comparative leaf anatomical features have been presented in Table 2. Glandular trichomes are found on the midrib of $P$. betle, $P$. longum, and $P$. sylvaticum, whereas trichomes are absent in $P$. nigrum and $P$. retrofractum. The highest number of collateral vascular bundles is noticed in $P$. retrofractum (4) followed by $P$. nigrum (3), while single collateral vascular bundle is present in $P$. betle and $P$. longum. Numerous idioblasts are observed in $P$. betle but absent in P. longum and P. sylvaticum.

Leaves of the studied species of Piper are found to be hypostomatic although amphistomatic is reported in P. hispidinervum C. DC. (Gogosz et al., 2012) and P. sarmentosum Roxb. (Raman et al., 2012). Different types of stomata viz., diacytic, paracytic, anomocytic, tetracytic and anisocytic are observed in all the studied species of Piper. P. longum can easily be differentiated from remaining species by its diacytic stomata (Table 2). Tetracytic stomata are common in Piper species (Santos et al., 2015; Bertocco et al., 2017). However, due to the presence of multiple types of stomata in case of inter- and intra- species this feature may not be helpful in the delimitation of species (Santos et al., 2018).

In our studied species of Piper the epidermis of midrib and lamina is uniseriate and covered with thin and smooth cuticle. Several studies have shown that leaf of Piper species exhibits single layered epidermis (Raman et al., 2012; Santos et al., 2015, 2018). However, multiple layered epidermis have been reported in Piper species (Gogosz et al., 2012; Raman et al., 2012). Midrib shape and vascular pattern are useful markers to differentiate and identify Piper species (Santos et al., 2018). Although midrib shape was biconvex in all the examined species, each of them has some variations on either surface (Table 2). Diversification in the shape of midrib is also precisely demonstrated in Figures 3A-E. However, Raman et al. (2012) reported flat-convex midrib in $P$. betle. Other shape such as concave-convex has also been found in Piper (Santos et al., 2015). As shown in Figure 3F generally in the adaxial surface beneath the epidermis, several layered angular collenchyma cells are present and the palisade parenchyma cells become gradually shorter toward the middle region. 


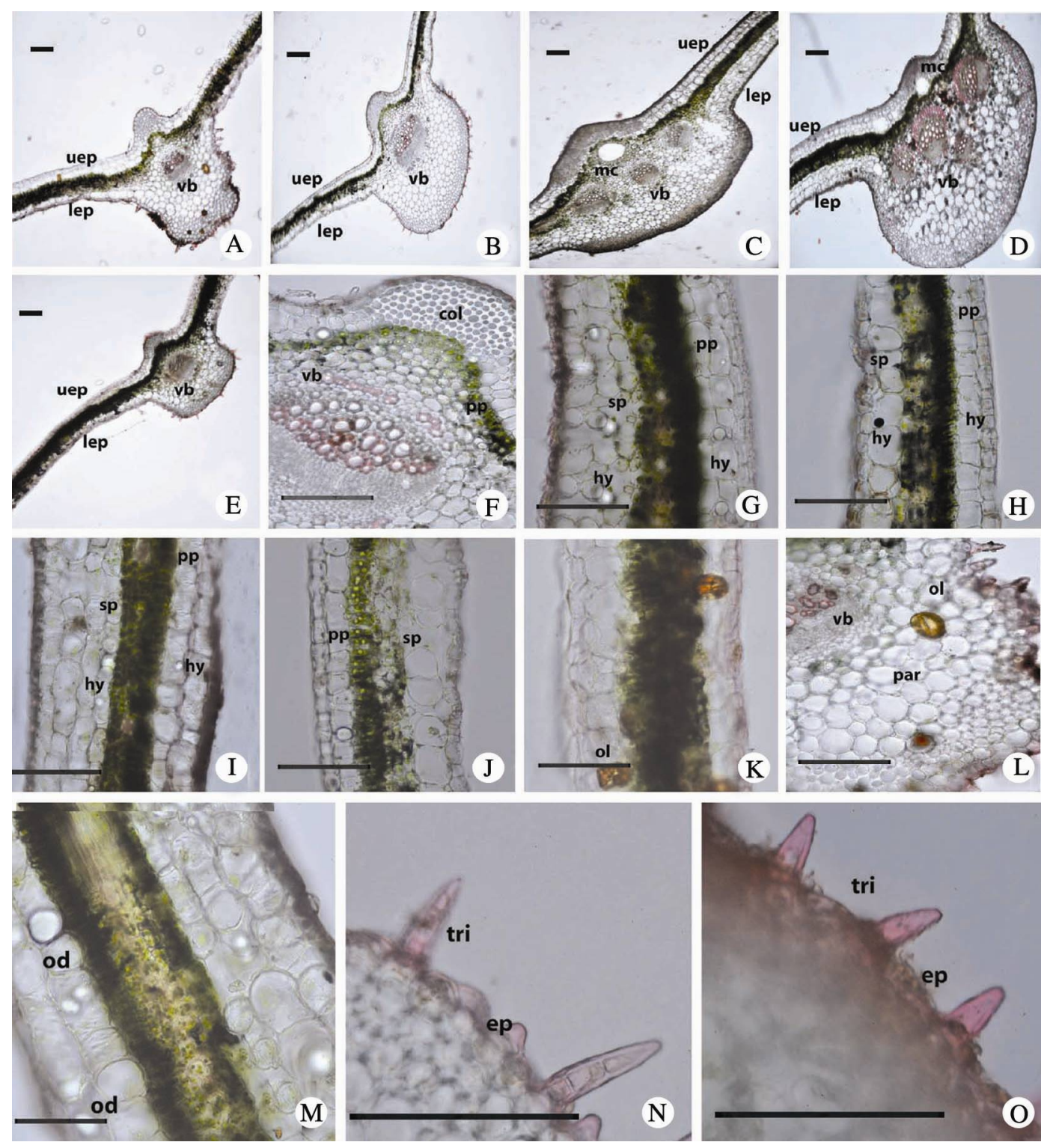

Fig. 3. Transverse section of leaf presenting anatomical features in the midrib and lamina of Piper species: A. $P$. betle $(10 \mathrm{X})$; B. P. longum (10X); C. P. nigrum (10X); D. P. retrofractum $(10 \mathrm{X})$; E. P. sylvaticum (10X); F. P. nigrum (40X); G. P. retrofractum (40X); H. P. longum (40X); I-J. P. nigrum (40X); K-L. P. betle (40X); M. $P$. nigrum (40X); N. Trichomes of P. longum (100X); O. Trichomes of P. sylvaticum (100X). uep: upper epidermis, lep: lower epidermis, vb: vascular bundle, mc: mucilage canal, col: collenchyma, pp: palisade parenchyma, sp: spongy parenchyma, hy: hypodermis, ol: oleoresins, od: oil droplets, ep: epidermis, tri: trichome. Bar $=100 \mu \mathrm{m}$.

The vascular system is represented by collateral vascular bundle in the ground parenchyma except in P. sylvaticum where it is bicollateral. Three discrete vascular bundles are found more or less in a straight line in P. nigrum (Fig. 3C), and in P. retrofractum three larger vascular bundles 
form a line, and the smallest vascular bundle is situated near the middle one (Fig. 3D). Crescent shaped sclerenchyma cells are observed surrounding the vascular bundle of $P$. retrofractum only (Fig. 3D).

In case of laminar portion, immediately beneath the upper and lower epidermis distinct hypodermal layers of hyaline parencyhmatous cells are notified. Nakamura et al. (2015) opines that the origin of the sub-epidermal layers or hypodermis in Piper leaves is the ground meristem. The number of hypodermal layers is considered by many authors as a taxonomic character to identify Piper species (Raman et al., 2012; Machado et al., 2015; Santos et al., 2015; Bertocco et al., 2017). The present investigation also confirms variable numbers of hypodermis on both surfaces across the species (Table 2). P. betle and P. retrofractum have similar number of hypodermis (Fig. 3G, K), while P. longum and $P$. sylvaticum have similar pattern of hypodermis (Fig. $3 \mathrm{H})$. However, $P$. nigrum differ from the remaining species by possessing maximum number of hypodermis (Fig. 3I).

In the studied species of Piper, 2 layers of palisade and 3-5 layers of spongy parenchyma with no or small intercellular spaces are observed (Fig. 3J). However, the number of layers of palisade and spongy parenchyma may vary in different species (Santos et al., 2015).

Table 2. Comparative anatomy of leaf of five studied species of Piper L.

\begin{tabular}{|c|c|c|c|c|c|}
\hline Features & P. betle & P. longum & P. nigrum & P. retrofractum & P. sylvaticum \\
\hline $\begin{array}{l}\text { Trichomes } \\
\text { (Glandular) }\end{array}$ & $\begin{array}{l}1-3 \text { celled, only } \\
\text { on abaxial } \\
\text { surface }\end{array}$ & $\begin{array}{l}1-3 \text { celled, only } \\
\text { on abaxial } \\
\text { surface }\end{array}$ & Absent & Absent & $\begin{array}{l}\text { Unicellular, many } \\
\text { on abaxial and } \\
\text { few on adaxial } \\
\text { surface }\end{array}$ \\
\hline Midrib shape & $\begin{array}{l}\text { Biconvex, } \\
\text { abaxial square } \\
\text { shaped with } \\
\text { ridges and } \\
\text { furrows, } \\
\text { adaxial more } \\
\text { angular }\end{array}$ & $\begin{array}{l}\text { Biconvex, } \\
\text { abaxial } \\
\text { semi-circled } \\
\text { with no ridges } \\
\text { and furrows, } \\
\text { adaxial angular }\end{array}$ & $\begin{array}{l}\text { Biconvex, } \\
\text { abaxial semi- } \\
\text { circled, } \\
\text { flattened with } \\
\text { no ridges and } \\
\text { furrows, } \\
\text { adaxial angular }\end{array}$ & $\begin{array}{l}\text { Biconvex, abaxial } \\
\text { bean shaped with } \\
\text { no ridges and } \\
\text { furrows, adaxial } \\
\text { less angular }\end{array}$ & $\begin{array}{l}\text { Biconvex, abaxial } \\
\text { semi-circled } \\
\text { somewhat } \\
\text { flattened, slightly } \\
\text { wavy, adaxial } \\
\text { angular }\end{array}$ \\
\hline Hypodermis & $\begin{array}{l}\text { Upper 2- } \\
\text { layered, lower } \\
\text { 3-layered }\end{array}$ & $\begin{array}{l}\text { Both upper and } \\
\text { lower 2-layered }\end{array}$ & $\begin{array}{l}\text { Upper 2- } \\
\text { layered, lower } \\
\text { 4-layered }\end{array}$ & $\begin{array}{l}\text { Upper 2-layered, } \\
\text { lower 3-layered }\end{array}$ & $\begin{array}{l}\text { Both upper and } \\
\text { lower 2-layered }\end{array}$ \\
\hline $\begin{array}{l}\text { Mucilage } \\
\text { canal }\end{array}$ & $\begin{array}{l}\text { Small, single, } \\
\text { present on } \\
\text { midrib VB } \\
\text { towards adaxial } \\
\text { surface }\end{array}$ & Absent & $\begin{array}{l}\text { Large, single, } \\
\text { present on } \\
\text { midrib VB } \\
\text { towards } \\
\text { adaxial surface }\end{array}$ & $\begin{array}{l}\text { Present on midrib } \\
\text { VB and also in } \\
\text { lamina on adaxial } \\
\text { side }\end{array}$ & Absent \\
\hline $\begin{array}{l}\text { Vascular } \\
\text { bundle }\end{array}$ & $\begin{array}{l}\text { Single, } \\
\text { collateral }\end{array}$ & $\begin{array}{l}\text { Single, } \\
\text { collateral }\end{array}$ & 3 , collateral & 4 , collateral & $\begin{array}{l}\text { Single, } \\
\text { bicollateral }\end{array}$ \\
\hline $\begin{array}{l}\text { Idioblasts and } \\
\text { oil droplets }\end{array}$ & Numerous & Absent & $\begin{array}{l}\text { Occasionally } \\
\text { present }\end{array}$ & $\begin{array}{l}\text { Occasionally } \\
\text { present }\end{array}$ & Absent \\
\hline Stomata & $\begin{array}{l}\text { Anomocytic, } \\
\text { Anisocytic }\end{array}$ & Diacytic & $\begin{array}{l}\text { Anomocytic, } \\
\text { Tetracytic }\end{array}$ & Paracytic & $\begin{array}{l}\text { Paracytic, } \\
\text { Tetracytic }\end{array}$ \\
\hline
\end{tabular}

Individual secretory cells (idioblasts) containing orange lipophilic content and resin (oleoresins) as well as oil droplets are abundant in the lamina as well as midrib region of $P$. betle (Fig. 3K-L) and occasionally appeared in $P$. nigrum and $P$. retrofractum. On the contrary, only oil droplets are observed in P. retrofractum, $P$. longum and P. nigrum (Fig. 3G-I). Such idioblasts 
have additional secretory functions and reported from many other species of Piper (Raman et al., 2012; Machado et al., 2015; Nakamura et al., 2015; Santos et al., 2015; Bertocco et al., 2017).

Conical shaped, non-glandular, unicellular to multicellular trichomes have been observed in the leaf of Piper species (Table 2). Significantly, trichomes are confined only in the midrib region of the leaf. P. betle and P. longum have multicellular, glandular trichomes (Fig. 3A,L \& B,N) confined only to the abaxial surface of midrib zone; whereas, unicellular trichomes are distributed on the midrib of both surfaces of $P$. sylvaticum (Fig. 3O). Trichomes are absent in P. nigrum and $P$. retrofractum leaf.

Based on anatomical characteristics a key to the investigated species of Piper is presented below:

1. Stem oval in shape; idioblasts and oil droplets numerous.

- $\quad$ Stem round in shape; idioblasts and oil droptels absent.

2. Ridges and furrows absent in the outline of stem; leaf vascular bundles 4.

- Ridges and furrows present in the outline of stem; leaf vascular 3 bundles 1 or 3 .

3. Upper hypodermis 2-layered, lower ones 4-layered; mucilage canal present on midrib vascular bundle; vascular bundles 3 .

- Both upper and lower hypodermis 2-layered; mucilage canal 4 absent; vascular bundle 1 .

4. Leaf vascular bundle collateral; stomata diacytic. P. longum

- Leaf vascular bundle bicollateral; stomata paracytic and tetracytic. P. sylvaticum

The present study on morphoanatomical profiles of five Piper species from Bangladesh is the first of its nature. Trichomes primarily serve as defense tissue, and provide worthy anatomical features to characterize the studied species of Piper. Besides, other anatomical traits, viz. section contour, number of vascular bundles, presence of mucilage canal in case of stem and layers of hypodermis, midrib shape, idioblasts and stomata of leaf are considered as distinctive characters for delimitation of the Piper species investigated. Inclusion of additional species employing additional tools would throw more light on better understanding of species delimitation and interspecific relationships of the genus Piper.

\section{References}

Bertocco, A.R.P., Migacz, I.P., Santos, V.L.P., Franco, C.R.C., Silva, R.Z., Yunes, R.A., Cechinel-Filho, V. and Budel, J.M. 2017. Microscopic diagnosis of the leaf and stem of Piper solmsianum C. DC. Microsc. Res. Tech. 80: 831-837.

Chaveerach, R., Kunitake, H., Nuchadomrong, S., Sattayasai, N. and Komatsu, H. 2002. RAPD patterns as a useful tool to differentiate Thai Piper from morphologically alike Japanese Piper. Science Asia 28: 221225.

Ghani, A. 2003. Medicinal Plants of Bangladesh (Second Edition). Asiatic Society of Bangladesh, Dhaka, Bangladesh, $603 \mathrm{pp}$.

Gogosz, A.M., Boeger, M.R.T., Negrelle, R.R.B. and Bergo, C. 2012. Anatomia foliar com-parativa de nove espécies do gênero Piper (Piperaceae). Rodriguésia 63: 405-417.

Greig, N. 2004. Introduction. In: Dyer, L.A. and Palmer, A.N. (Eds), Piper: a Model Genus for Studies of Phytochemistry, Ecology, and Evolution. Kluwer Academic/Plenum Publishers, New York, pp. 1-4.

Habib, M.A. 2009. Piperaceae. In: Ahmed, Z.U., Hassan, M.A., Begum, Z.N.T., Khondoker, M., Kabir, S.M.H., Ahmad, M. and Ahmed, A.T.A. (Eds), Encyclopedia of Flora and Fauna of Bangladesh, Vol. 9, Angiosperms: Dicotyledons (Magnoliaceae-Punicaceae). Asiatic Society of Bangladesh, Dhaka, pp. $370-378$. 
Hooker, J.D. 1886. The Flora of British India. Vol. 6. L. Reeve \& Co., London, UK, pp. 78-99.

Hubert, H. 1987. Piperaceae. In: Dassanayake, M.D. and F.R. Fosberg (Eds), A Revised Handbook to the Flora of Ceylon, Vol. 6. Amerind Publishing Co. Pvt. Ltd., New Delhi, India, pp. 272-300.

Jaramillo, M.A. and Callejas, R. 2004. Current Perspectives on the Classification and Phylogenetics of the Genus Piper L. In: Dyer, L.A. and Palmer, A.D.N. (Eds), Piper: A Model Genus for Studies of Phytochemistry, Ecology, and Evolution. Kluwer Academic/Plenum Publishers, New York, pp. 179198.

Jaramillo, M.A. and Manos, P.S. 2001. Phylogeny and patterns of floral diversity in the genus Piper (Piperaceae). Am. J. Bot. 88(4): 706-716.

Lakshmi, B.S. and Naidu, K.C. 2010. Comparative morphoanatomy of Piper betle L. cultivars in India. Annals Biol. Res. 1(2): 128-134.

Machado, N.S.O., Pereira, F.G., Santos, P.R.D., Costa, C.G. and Guimarães, E.F. 2015. Comparative anatomy of the leaves of Piper lepturum (Kunth) C. DC. var. lepturum and Piper lepturum var. angustifolium (C. DC.) Yunck. Hoehnea 42: 1-8.

Murty, Y.S. 1973. Studies in the Order Piperales. IV. A contribution to the study of vegetative anatomy of three species of Piper. Proc. Nat. Inst. Sci., India 25(B): 31-38.

Nakamura, A.T., Simão, E., Silva, L. and Torres, G.A. 2015. Origin of the sub-epidermal tissue in Piper L. leaves. Braz. J. Biol. 75: 368-371.

Prain, D. 1903. Bengal Plants, Vol. 2. Botanical Survey of India, Calcutta, pp. 267-269.

Raman, V., Galal, A.M. and Khan, I.A. 2012. An investigation of the vegetative anatomy of Piper sarmentosum, and a comparison with the anatomy of Piper betle (Piperaceae). Am. J. Plant Sci. 3: 1135-1144.

Ravindran, P.N. and Remashree, A.B. 1998. Anatomy of Piper colubrinum Link. J. Spices \& Aromat. Crops 7(2): 111-123.

Santos, V.L.P., Franco, C.R.C., Amano, E., Messias-Reason, I.J. and Budel, J.M. 2015. Anatomical investigations of Piper amalago (Jaborandi-manso) for the quality control. Rev. Bras. Farmacogn. 25: $85-91$.

Santos V.L.P., Raman, V., Bobekc, V.B., Migaczc, I.P., Franco, C.R.C., Khan, I.K. and Budel, J.M. 2018. Anatomy and microscopy of Piper caldense, a folk medicinal plant from Brazil. Rev. Bras. Farmacogn. 28: 9-15.

Shethi, K.J., Begum, M. and Rashid, P. 2017. Comparative anatomy of Momordica dioica Roxb. ex Willd. and M. cochinchinensis (Lour.) Spreng. Bangladesh J. Bot. 46(2): 725-732.

Silva, R.J.F., Aguiar-Dias, A.C.A. and Mendonca, M.S. 2014. Rosetas e concrescên-cias cristalinas silicificadas em Piper (Piperaceae): registros inéditos demacropadrões. Acta Amaz. 44: 435-446.

Silva, R.J.F., Aguiar-Dias, A.C.A., Faial, K.C.F. and Mendonca, M.S. 2017. Morphoanatomical and physicochemical profile of Piper callosum: valuable assessment for its quality control. Rev. Bras. Farmacogn. 27: 20-33.

Sinha, S.C. 1996. Medicinal plants of Manipur. MASS and SINHA, Manipur Cultural Integration Conference Palace Compound, Imphal, India, $288 \mathrm{pp}$.

The Plant List, 2013. The Plant List, a working list of all plant species. Version $1.1<$ http://www.theplantlist.org/>. Accessed on 2 February 2019.

TROPICOS, 2017. Tropicos.org. <www.tropicos.org>. Missouri Botanical Garden, Saint Louis, Missouri, USA. Accessed on 2 February 2019.

Trueba, S., Rowe, N.P., Neinhuis, C., Wanke, S., Wagner, S.T. and Isnard, S. 2015. Stem anatomy and the evolution of woodiness in Piperales. J. Plant Sci. 176: 468-485.

Yongqian, C., Nianhe, X. and Gilbert, M.G. 1999. Piperaceae. Flora of China, 4: 110-129. 